C 114

\title{
熱画像解析による翼表面流れのはく離検出
}

\author{
谷合 哲弥 (東京理科大学)，大林 弘史 (東京地下鉄 (株)) \\ 山口环人（東京理科大学）, 石川 仁（東京理科大学） \\ 山田 俊輔 (東京理科大学)，徳川直子 (宇宙航空研究開発機構)
}

\section{Detection of Flow Separation on Aerofoil using Thermal Image Analysis}

\author{
Tetsuya TANIAI, Hiroshi OHBAYASHI \\ Takuto YAMAGUCHI, Hitoshi ISHIKAWA \\ Shunsuke YAMADA and Naoko TOKUGAWA
}

ABSTRACT

\begin{abstract}
The purpose of this study is to detect flow separation on aerofoil using thermal image analysis. A NACA0018 wing and a flat plate wing were used as test pieces, pre-heated by a hair-drier to thermographic measurements. An infrared camera took thermal images of surface temperature distribution on the aerofoil. It was found that surface temperature distribution was an important factor determining the separation and the reattachment point. The result shows the infrared image technique is effective method for detection of flow separation.
\end{abstract}

Keywords : Flow separation, Reattachment, Thermal image, Infrared Measurement, Flow visualization

\section{1. 緒 㐫}

物体表面近くの流れを可視化するために，直接注入トレー サ法や表面トレース法, タフト法などの様々な手法が提案さ れている 1,2). 本研究では，琵表面上の流れを亦外線力メラ の䓡画像を用いて可視化し，はく離・再付着点の位置やはく 傩のパターンを明らかにすることを目的とする.この赤外線計 測法は, 層流境界層と乱流境界層で物体裁面の熱伝達特 性が異なることを利用し，これに起因する翼表面の温㡲分布 を赤外線カメラで捉え，熱画像を得ることで流れを可視化す るむのである. 熱画像による可視化法は, リアルタイムの面計 測が可能で, 非接触なため物体表面の流れを乱さないとい った利点がある 3 .

本研究では，流速の小さい低レイノルズ数の翼表面の流 れを対象とした．超音速流や極超音速流中の場合と違い，低 レイノルズ数の楒表面に熱伝達率の違いによる温度差が自 然に生じることはないが, 徳川ら 4)が行った翼表面を一様に 予熱寸る方法により翼面に温度差を生じさせ，赤外線計測を 可能にした. 実験は供試体として NACA0018 翼と平板翼を 用いて行い，それぞれ迎角を変化させたときの様子を赤外線 カメラにより計測した. また, 赤外線計測で得られる結果の妥 当性を確がるため，表面タフト法による可視化を併用して 行い, 赤多線計測の結果と比較し検証した.

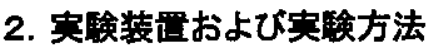

Fig.1に実験の模式図および座標系を示す.実験には
出口寸法 $250 \mathrm{~mm} \times 250 \mathrm{~mm}$ の吹き出し型風洞を使用した. 供試体となる NACA0018 翼(以後 NACA 翼と呼ぶ)は翼弦 長 $C=111 \mathrm{~mm}$ ，平板翼は $C=110 \mathrm{~mm}$ ，翼幅 $S$ はいずれも $230 \mathrm{~mm}$ である. 平板翼の翼厚は $10 \mathrm{~mm}$ とし, NACA 翼 は中空棰造となっている，材質はどちらの翏も ABS 橉 脂であり，その熱伝導率は $0.17 \sim 0.21 W /(\mathrm{m} \cdot \mathrm{K})$ である. なお， NACA 翼には翼上下面に静圧孔を設けてあり，平板翼は前 縁を鋭角 $\left(30^{\circ}\right)$ に切り落としてある. 翼両端には二次元性を確 保寸るため, 直径 $200 \mathrm{~mm}$, 厚さ $1 \mathrm{~mm}$ の円形の端板を取り 付けた，翼は迎角 $\alpha$ を細かく調整できる回転ステージに取り 付け，風洞出口から $200 \mathrm{~mm}$ 下流に設置した。

表面タフト法で使用したタフトは長さを $8 \mathrm{~mm}$ とし, 材料は 刺紻用絹糸を用いた. 流れの特徵が得られやすい翼前縁付 近証，タフトを複数列設け， $x$ 方向の設置間隔は前後のタフト に影䑕を与えない程度とした。

実験は主流流速 $U_{\infty}$, 翼弦長 $C$, 動粘性係数 $v$ とし, $\operatorname{Re}\left(=U_{\infty} C_{v}\right) \doteqdot 98,000$ で行った。翼面をあらかじめへア・ドラ イヤー(出力 $1200 \mathrm{~W}$ )で一様に加熱した後，通風開始 $(t=0 \mathrm{~s})$ と同潞に赤外線カメラにて翼面が冷やされる栐子を撮影し， 熱画像を得た. 熱画像の温度差解析山全て $y / S=0.50$ の 位置で行った。迎角 $\alpha$ は NACA 翼では $\alpha=0 \sim 30^{\circ}$, 平板翼 では $\alpha=-5 \sim 10^{\circ}$ に変化させて行った. NACA 翼では翼上下 面の静圧が等しくなる角度を，平板翼では風洞出口に対し幾 何的に $\alpha=0^{\circ}$ となる角度を，それぞ机迎角 $\alpha=0^{\circ}$ とした. なお， 赤外線カメラは，日本アビオニクス社製の Neo Thermo TVS-700を用いた。 


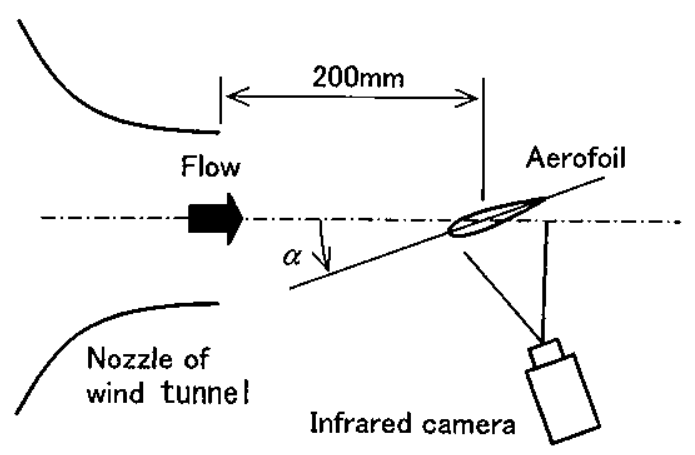

(a) Sketch of infrared measurement system

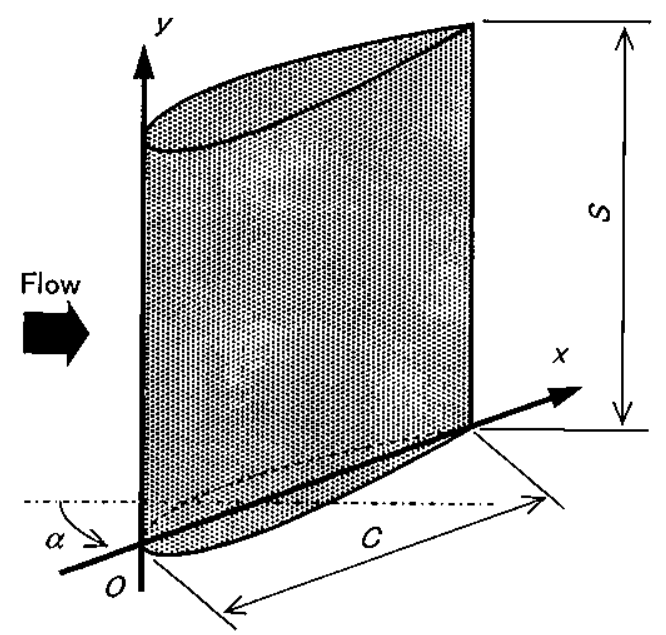

(b) Coordinate system

Fig. 1 Experimental setup.

\section{3. 实験結果および孝察}

$\mathrm{NACA}$ 翼と平板翼の時刻 $t=0 \mathrm{~s}$ と $t=60 \mathrm{~s} に お け る$ 表面温 度 $T_{0}$ と $T_{60}$ の熱画像を赤外線計測により得ることができる. 熱画像の例として NACA 翼の $\alpha=0^{\circ}$ の場合を Fig.2 に示す. これらの熱画像より, $t=0 \mathrm{~s}$ と $t=60 \mathrm{~s}$ の表面温度美 $T_{0} \cdot T_{60}$ を 差分画像として求め, これを $y / S=0.50$ の位置で温度解析す ることで翼弦方向の表面温度差分布を得る. NACA 翼と平 板翼の各迎角におりる表面温度差分布を Fig.3, Fig.4 に示 す. Fig.3 より, NACA 翼では $\alpha=0 \sim 14^{\circ}$ で前秝から温度差が 減少，増加，堿少，増加といった分布を示し，温度差分布に 極大と極小があることがわかる.この極大・極小の位置は， $\alpha$ の增大と共に上流側入移動している. $\alpha=15 \sim 30^{\circ}$ では, 温度 差分布は $x C=0.10$ 付近で最小值を取り，それより下流では 比較的平坦な分布を示している. 一方, Fig.4 より平板翼につ いては, $\alpha=5^{\circ}$ では前緣から温度差が単調に減少している. $\alpha=0 \sim 7^{\circ}$ では温度差分布に極大・極小が見られ，それらが $\alpha$

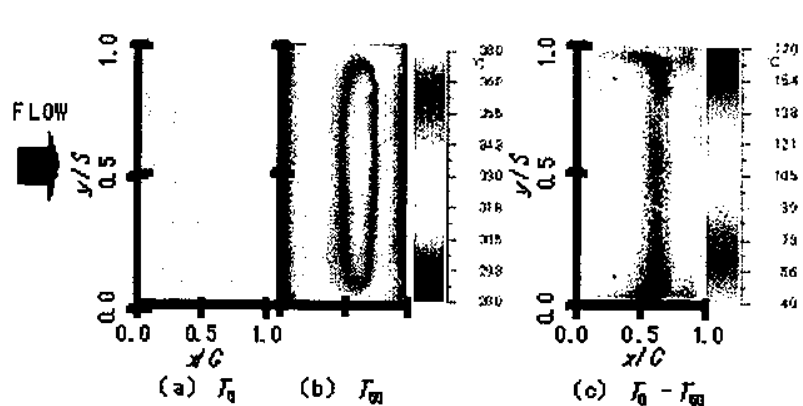

Fig. 2 Surface temperature and temperature difference on the surface of NACA0018 wing $\left(\alpha=0^{\circ}\right)$.

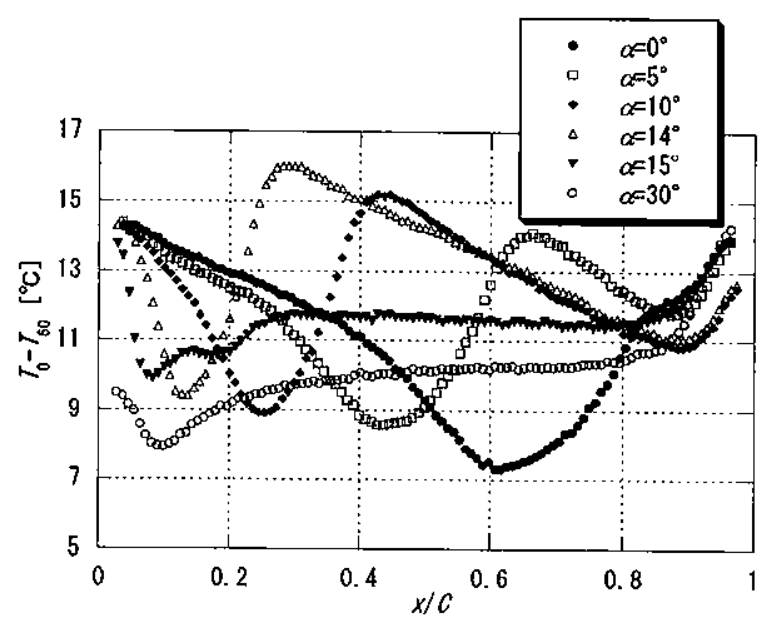

Fig. 3 Distributions of temperature difference on the surface of NACA0018 wing.

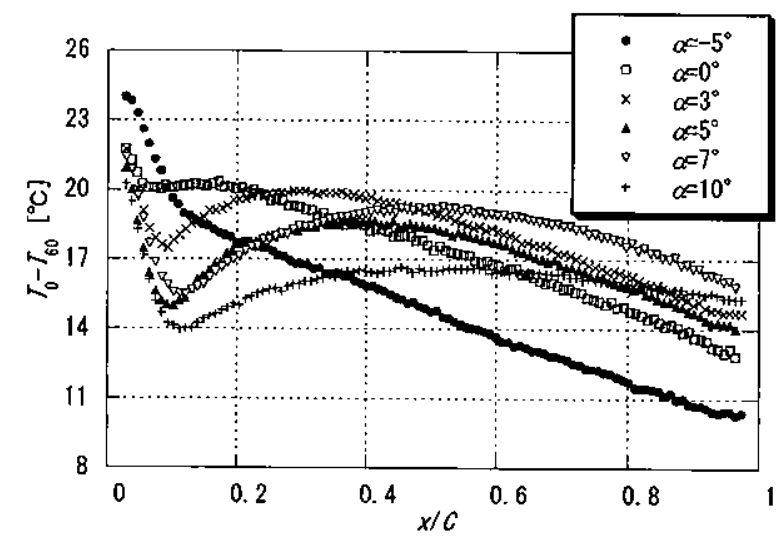

Fig. 4 Distributions of temperature difference on the surface of flat plate wing.

の増大と共に下流側入移動している. $\alpha=10^{\circ}$ は NACA 翼の $\alpha=15 \sim 30^{\circ}$ と同様, 温度差分布が平坦な形状を取っており, 極大·極小值は見られない.

一般に, 再付着点では熱伝達率が最大值を示すことが知 られており，またはく雕点では熱伝達率が極小となることが報 
告されている ${ }^{5,6)}$.このことを踏まえて上述した温度差分布を 見てみると, NACA 翼の $\alpha=0 \sim 14^{\circ}$ と平板翼の $\alpha=0 \sim 7^{\circ}$ ではく 離·再付着が, $\mathrm{NACA}$ 䍂の $\alpha=15 \sim 30^{\circ}$ と平板翼の $\alpha=10^{\circ}$ では 前縁付近からの大規模なはく離が生じている可能性がある.

このことを確かめるために, 翼面にタフトを設置し,タフトの 振舞いを観察した. タフトの振舞い怢 Table 1 に示す 3 つの

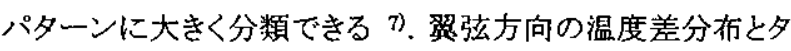
フトの観察結果を NACA 翼と平板嫼それぞれについて比較 した. その比較結果を NACA 翼については Fig.5 に, 平板 翼については Fig.6 に示寸，各糸弦位置におけるタフトの振 舞いを図中に矢印で示してある.

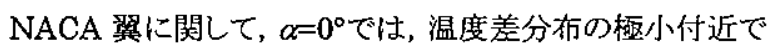
タフトが安定から不安定へ変化していることがわかる， $\alpha=14^{\circ}$ では, タフトの様子から流れがはく離・再付着を起こしている ことがわかる. タフトが示すはく離点の位置では温度差分布 は極小となっており，再付着点の位置では温度差分布仕極 大となっている. $\alpha=30^{\circ}$ では, タフトは流れが前縁付近から完 全にはく離を起こしていることを示し，はく離点の位置が $\alpha=14^{\circ}$ と同様に温度差分布の極小の位置と一致している.

一方, 平板翼に関しては， $\alpha=-5^{\circ}$ では夕フトは翼全体にわ たって安定で, 翼面の流れが層流であることを示している. $\alpha=3^{\circ}$ では, タフトの動きから流れが翼前縁付近ではく截し， その後, 温度差分布が極大となる点で再付着していることが

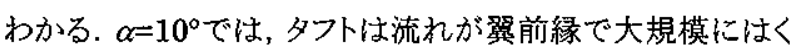
雇を起こしていることを示している。

以上のことから，表面の流れがはく雕・再付着を起こす場 合、はく離点は温度差が極小となる点に, 再付着点は温度差 が極大となる点にそれぞれ対応すると考えられる.また，流れ が巽前縁付近から大規模にはく離を起こす場合は, 温度差 分布は平坦な，大きなと゚ークの見られない形状をとることがわ かった.これは翟面全体に逆流・再循環領域汃形成され，翼 面温度が低下しにくくなているためと考えられる.

ただし，Fig.3 および Fig.4 からわかるように，NACA 翼で は後緣付近で, また平板翼では前縁付近で温度差が迎角の 変化に関保なくほぼ同様の大きい值を示している.これは, この筈囲の翼弦位置では翼厚が薄いため，翟面がよく冷え 温度差が大きくなったためと考えられる.したがって, 平板翼 ではこの翼厚の薄い部分の影響から，はく権点は温度差が 極小となっている位置よりも上流の前縁付近にあることも予想

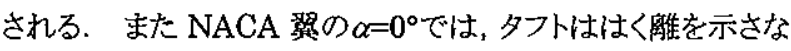
かったが，これ低低迎角に拉けるは離泡の厚さが夕フトの大 きさに対して小さかったため,タフトがはく脽を検出できな かったと考えられる. 実際に NACA0018 翼に対して行われ た油膜法による可視化実験 8)で， $\propto=0$ なよ゙の浅い迎角でも，
Table 1 Tuft patterns.

\begin{tabular}{|c|l|l|}
\hline Pattern & \multicolumn{1}{|c|}{ Behavior of tuft } & Picture \\
\hline $\begin{array}{c}\text { Steady } \\
\text { flow }\end{array}$ & Tuft doesn't move. & - \\
\hline $\begin{array}{c}\text { Unsteady } \\
\text { flow }\end{array}$ & $\begin{array}{l}\text { Tuft is oscillating or shows } \\
\text { pattern of Separation flow } \\
\text { for a little. }\end{array}$ & $\ldots$ \\
\hline $\begin{array}{c}\text { Separation } \\
\text { flow }\end{array}$ & $\begin{array}{l}\text { Tuft points upstream or } \\
\text { toward parallel walls. }\end{array}$ & $\ldots$ \\
\hline
\end{tabular}

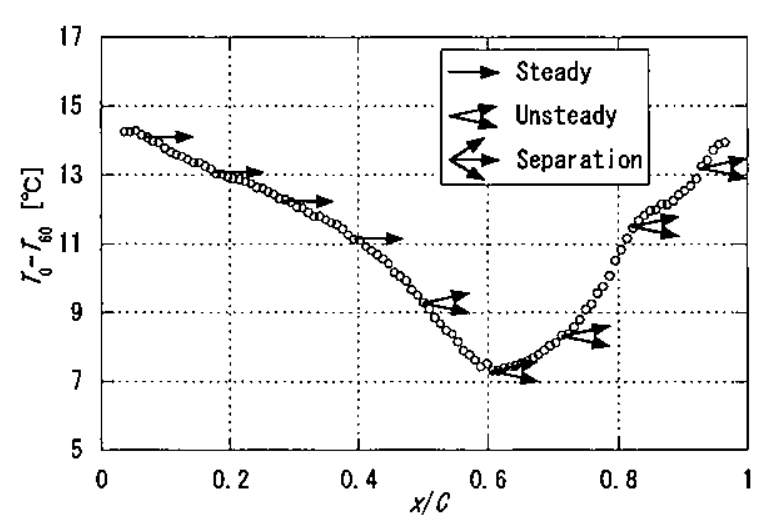

(a) $\alpha=0^{\circ}$

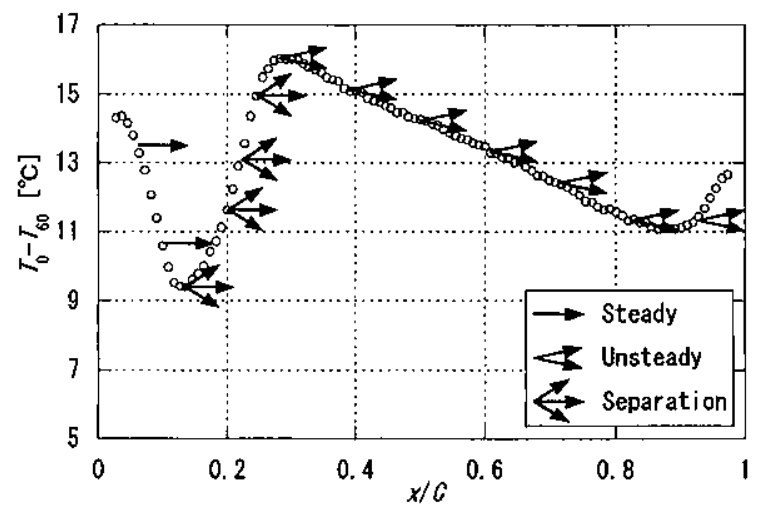

(b) $\alpha=14^{\circ}$

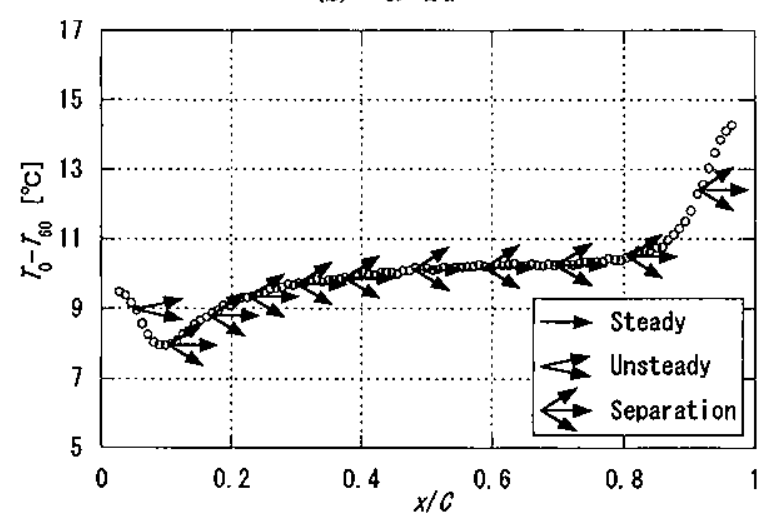

(c) $\alpha=30^{\circ}$

Fig. 5 Temperature analysis and tuft pattern on NACA0018 wing. 


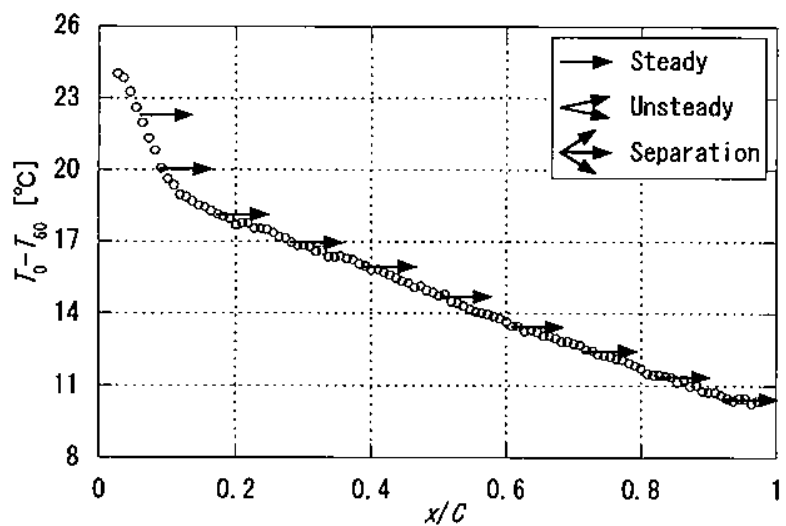

(a) $\alpha=5^{\circ}$

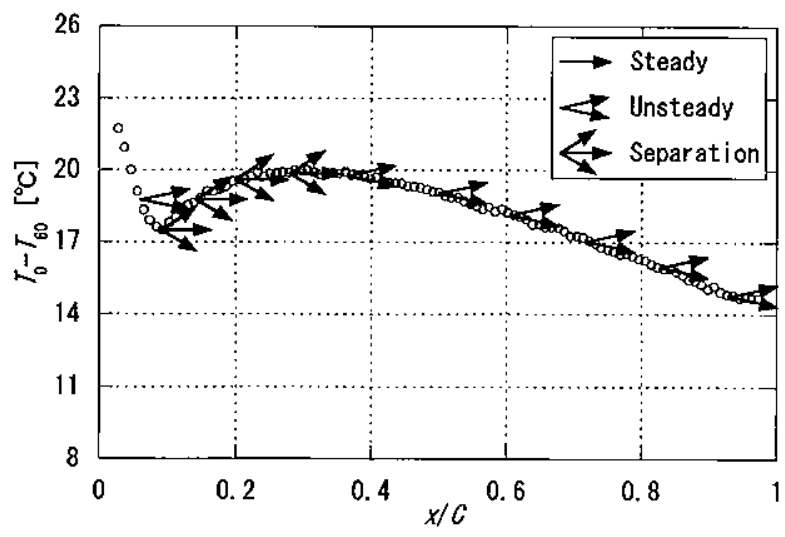

(b) $\quad \alpha=3^{\circ}$

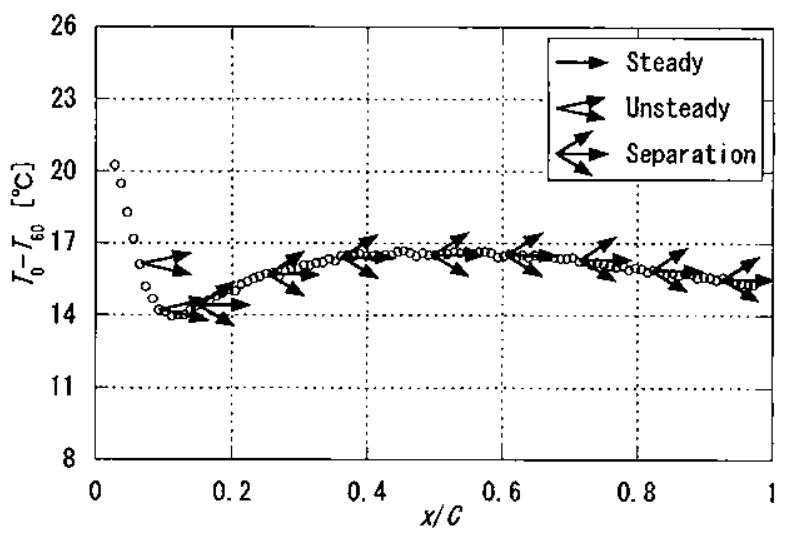

(c) $\alpha=10^{\circ}$

Fig. 6 Distribution of temperature difference and tuft pattern on flat plate wing.
はく離が起きることが報告されている。

以上より, 各翼に対する温度分布からのはく雄・再付着の 予測は夕フトの検証よりおおよそ正しいといえ，次のようにまと めることができる. NACA 翼の $\alpha=0 \sim 14^{\circ}$ と平板翼の $\alpha=0 \sim 7^{\circ}$ では，はく離·再付着が起きており，忧離・再付着点は迎角 が大きくなると共に NACA 巽では上流側へ，平板翼では下 流側一移動する. また, NACA 叕の $\alpha=15 \sim 30^{\circ}$ と平板翼の $\alpha=10^{\circ}$ については, 再付着することなく前縁付近で層流はく 離を起こす。

\section{4. 結 言}

本研究では NACA0018 翼および平板翼まわりの流れに 対して赤外線計測を行った. 得られた結果は以下の通り である.

[1] 低レイノルズ数領域における, 赤外線熱画像の翼表 面のはく離・再付着流れの解析への有效性を示した.

[2] NACA 翼の $\alpha=0 \sim 14^{\circ}$ と平板翼の $\alpha=0 \sim 7^{\circ}$ の) ときのように, 翼表面流れには離·再付着が起こる場合, はく離点お よび再付着点は，表面温度差が極小となる点および＼cjkstart極 大となる点から検出できる.

[3] $\mathrm{NACA}$ 翼の $\alpha=15^{\circ}$ 以降之平板翼の $\alpha=10^{\circ}$ 以降のときのよ うに, 翼前縁で流れがはく離した場合, 表面温度差は大き いピークが見られない平坦な分布を示すことがわかった。

\section{参考文献}

1）流れの可視化学会：流れの可視化ハンドブック，朝倉 整店, (1986)

2）笠木伸英 他：流体実験ハンドブック，朝倉書店， (1997).

3） 中村元：赤外線で襣た乱流伝熱の世界，可視化情報， Vol.29, No.113(2009) pp.116-121.

4）徳川直子 他：矩形翼境界層の自然悬移に対劣る外乱の 影瞳，日本流体力学会誌「ながれ」，Vol.24，(2005) pp.629-639.

5）森康夫，土方邦夫：流扎と熱の工学 II，共立出版 (1977).

6）藤田秀臣 他：壁面近傍におかれた二次元円柱が平板 强制対流熱伝達におよぼす影㗽，日本機械学会論文集， Vol.47-414, B (1981) pp.317-325.

7) Sagi, C.J. et al.: THE DESIGN AND PERFORMANCE OF TWO-DIMENSIONAL CURVED SUBSONIC DIFFUSERS, Report PD-9, Stanford University,(1965) .

8）䏚沢延行：二次元翼から発生する空力騷音と茲周りの 流れの可視化，可視化情報，Vol.21，No.9(2001) pp.123129. 